\title{
РЕЦЕНЗІї
}

УДК 94(100):355.415.8(470+571)«1914-1918»

DOI: 10.31470/2518-7600-2018-6-287-301

«NATIONAL FOOTPRINT» IN O. S. NAGORNAYA'S

BOOK ABOUT PRISONERS OF WAR OF THE TSARIST

ARMY IN GERMANY (1914-1922): UKRAINIAN

HISTORIAN'S POLEMICAL NOTES

\section{«НАЦИОНАЛЬНЫЙ СЛЕД» В КНИГЕ \\ О. С. НАГОРНОЙ О ВОЕННОПЛЕННЫХ ЦАРСКОЙ \\ АРМИИ В ГЕРМАНИИ (1914-1922 ГГ.): \\ ПОЛЕМИЧЕСКИЕ ЗАМЕТКИ УКРАИНСКОГО ИСТОРИКА}

\section{Игорь Срибняк,}

доктор исторических наук, профессор, зав. кафедрой всемирной истории историкофилософского факультета i.sribniak@kubg.edu.ua orcid.org/0000-0001-9750-4958 ID: O-1143-2018

Киевский университет имени Бориса Гринченка 04212, Украина, Киев, ул. Тимошенко, 13-Б, к.415
Ihor Sribnyak,

Doctor of Sciences in History, Professor, Head of the

Department of World History of Historical-philosophical faculty

i.sribniak@kubg.edu.ua orcid.org/0000-0001-97504958

ID: O-1143-2018

Borys Grinchenko Kyiv

University

04212, Ukraine, Kyiv,

Tymoshenka Str., 13-B, of.415

\section{ABSTRACT}

In the review in a polemical form judgments about the content of one of the sections of the monograph O. Nagorna "Another military experience. Russian war prisoners of the first world war in Germany (1914-1922)», which was published in 2010 in the Moscow publishing house "Chronograph». The book was prepared in the framework of the research project of the University in 
Tübingen (Germany) «Military experience, war and society in the new time» and was published thanks to the financial support of the German research community. The author of the monograph synthesized a very representative range of sources, including a significant number of archival documents from German and Russian archives, materials of the camp press, etc. The book of $O$. Nagorna significantly expanded our understanding of the camp daily life of prisoners of war of the royal army, bringing the reader, in fact, to a new - qualitatively higher-level of knowledge about this problem.

The section of her book "German Policy of Enlightening National Minorities of the Russian Empire: Stereotypes, Propaganda and Perception» is read with particular interest, where O. Nagorna touched the problem of national camps, and in particular - the Ukrainian soldiers (Rastat, Wetzlar, Salzwedel) and officers in Hanover-Münden. And if talking exclusively about how O. Nagorna information was presented about the Ukrainians - war prisoners (as well as representatives of other nations), we have to admit that the author in many respects remained faithful to the old hackneyed recipes in covering the political aspirations of these rather numerous national groups of prisoners of war of the Russian Imperial Army. In the perception of O. Nagorna-national patriotic work, which was conducted in the Ukrainian camps by members of the Union for the Liberation of Ukraine, a priori could not have a positive character, because objectively weakened tsarist Russia.

Key words: war prisoners, camp, Ukrainians, Russian Empire, First World War.

Можно было бы предположить, что появление в 2010 г. на российском книжном рынке монографии О. Нагорной «Другой военный опыт. Российские военнопленные первой мировой войны в Германии (1914-1922)» (Москва: Новый Хронограф, 2010. 440 с.) станет отрадным фактом, уже выходя из тематики её исследования. Важным обстоятельством являлось, прежде всего, то, что эта работа была подготовлена в рамках исследовательского проекта Университета в Тюбингене (Германия) «Военный опыт, война и общество в новое время» и вышла в свет благодаря финансовой поддержке 
Немецкого исследовательского сообщества. Уже исходя из этого можно было бы надеяться, что синтезированный в упомянутой книге материал позволит её читателям, и в частности - российским историкам (хотя и украинским тоже), по-новому взглянуть на проблему военнопленных царской армии во время Первой мировой войны.

Следует отдать должное О. Нагорной, которая в целом оправдала эти ожидания, - обработав и использовав в своей монографии весьма репрезентативный круг источников, в т.ч. значительное количество архивных документов из немецких и российских архивохранилищ, материалы лагерной прессы, публицистику и др. Книга О. Нагорной существенно расширила наши представления о лагерной повседневности военнопленных царской армии, выведя читателя, по сути, на новый - качественно высший - уровень знаний об этой проблеме.

С особенным интересом читается тот раздел из её книги («Немецкая политика просвещения национальных меньшинств Российской империи: стереотипы, пропаганда и восприятие»), в котором О. Нагорная коснулась проблемы национальных лагерей, и в частности - украинских солдатских (Раштат, Вецляр, Зальцведель) и офицерского в Ганновер-Мюндене. И если говорить исключительно о том, как была преподнесена О. Нагорной информация о военнопленных украинцах (равно как и представителей других наций), приходится констатировать, что автор во многом осталась верна старым заезженным рецептам в освещении политических устремлений этих достаточно многочисленных национальных групп военнопленных Российской императорской армии.

Прежде всего - каждый серьезный исследователь при этом считал бы своим долгом проанализировать современную украинскую историографию проблемы, но видимо эта аксиоматическая установка для каждого историка еще не стала правилом для О. Нагорной. Поэтому её историографический обзор не содержит ни малейшей информации о вышедших до 2010 г. статей и книг украинских авторов (Срібняк I., 1997; $1997 ; 1998 ; 1999)$ - для О. Нагорной их как бы не существует. Уже это обстоятельство даёт основание предположить 
определенную тенденциозность автора данной монографии в освещении «национальной» тематики.

Стиль и тональность изложения материала в книге О. Нагорной позволяют утверждать, что автор и не пыталась объективно и беспристрастно проанализировать те события, которые происходили в упомянутых лагерях военнопленных царской армии. Как известно, в них, благодаря усилиям Союза освобождения Украины (СОУ), велась интенсивная культурнообразовательная и национально-патриотическая работа, имеющая своей целью пробуждение национального самосознания украинцев (Срібняк, 2016). Однако стремление украинцев (равно как и поляков, грузин, крымских татар и др.) к построению собственных национальных государств априори вызывали у О. Нагорной скрытое неприятие, мало маскируемое видимостью «объективности». Поэтому неудивительно, что любым национальным чаяниям подневольных Российской империи народов О. Нагорная тут же навешивала ярлык «сепаратизма», что лишний раз свидетельствовало об её заангажированности.

На с. 168 своей книги О. Нагорная подаёт обширную цитату из предписания Прусского военного министерства (ПВМ), которой пытается доказать уже давно доказанное - что целью проводимой немцами пропаганды в лагерях являлась долгосрочная гарантия немецких послевоенных интересов. При этом следует отметить, что упомянутый «немецкий интерес» отвечал интересам независимой Украины, существование которой не могли себе даже в самом страшном сне представить правящие российские элиты на том этапе её развития.

Вместе с тем - чьи интересы должны были блюсти немцы - уж не российские ли? Естественно - только свои собственные, и было бы смешным утверждать обратное. Российский истеблишмент не оставлял ни единой возможности для выживания украинцев как отдельной нации с собственными политическими стремлениями, которые могли быть реализованы только в рамках национального государства. Поэтому пронемецкая ориентация была если не единственной возможностью для самосохранения украинцев, то, во всяком случае, одной из основных. 
Предвзятое отношение О. Нагорной к «украинскому вопросу» прорвалось и на с. 179 , где автор сообщает о том, что «офицеры-украинцы в смешанных лагерях, ранее скрывавшие свои националистические (курсив мой - И.С.) воззрения, начали требовать перевода в отдельный лагерь, и открыто заказывать агитационную литературу». Используя термин «националистические», О. Нагорная пыталась усилить, таким образом, негативную коннотацию, представив эту категорию военнопленных офицеров российской армии как «двурушников» и «предателей», «вонзающих нож в спину» воюющей России.

В этой связи представляется целесообразным «открыть глаза» О. Нагорной на действительные состояние дел в среде военнопленных офицеров-украинцев до 1918 г. - среди них практически отсутствовали «националисты». К этой категории можно было отнести лишь нескольких офицеров из их числа, в частности поручика Николая Шаповала, прапорщиков Николая Гладкого, Федора Пархотюка и еще нескольких их единомышленников (Срібняк, 1996; 2017).

В то же время - значительное большинство офицеровукраинцев даже и после падения империи продолжали придерживаться автономистских взглядов, не имея ни сил, ни желания решительно от них отказаться. Тем не менее, и в среде этого «болота» происходили важные изменения, одно из которых верно подметила О. Нагорная - риторика их обращений в немецкое военное ведомство свидетельствовала «об активном присвоении ими предложенных сверху образов толкования действительности» (с. 217). Таким образом, можно сделать вывод, что Союз освобождения Украины сумел достучаться до их сердец, заставив задуматься о судьбах создающейся украинской государственности.

Различия национальных характеров, о коих упоминали в своих дискуссиях с россиянами украинцы, также не были и не могли быть восприняты О. Нагорной - причем настолько, что подавая информацию об этом, она использует термин «малоросс» для обозначения украинцев. Собственно, «малороссами» называли тех украинцев, которые считали себя частицей «русского мира», идя на поводу у русских 
шовинистов - последовательных противников украинской государственности. Говорить о разнице в их характерах также не приходится - т. к. обладать «характером» могли только черносотенцы, а малороссы только обслуживали их интересы. Однако обозначить «малороссом» сознательного украинца тут была нужна отвага и последовательность, которую и продемонстрировала О. Нагорная в своих ничтожных попытках уничижения Украины.

На с. 180 О. Нагорная поделилась с читателем своими наблюдениями о том, что «часть военнопленных (речь идет об украинцах - И.С.) пыталась использовать проводимую политику привилегий в личных интересах». В данном случае О. Нагорная - под «политикой привилегий» - подразумевала те преимущества, которые предоставлялись представителям разных народов в «пропагандистских» («просветительных») лагерях с целью улучшения их лагерного быта. Такая практика могла иметь различные проявления (разовое или регулярное получение небольших денежных сумм, освобождение от обязательных работ, прогулки вне лагеря и др.).

Все это имело значение, однако наиглавнейшею причиною перевестись в украинский лагерь была та, что сознательные украинцы подвергались в смешанных лагерях каждодневной травле («притеснениям со стороны русских офицеров» - так дипломатично сглаживает действительное состояние в них О. Нагорная) со стороны шовинистически настроенных военнопленных. Однако насколько «хороши» были «гонители» украинцев стало понятно после подписания Брестского мира и распространения слухов об отправке домой военнопленных украинцев. Значительное количество россиян немедленно заявило о своей принадлежности к «малороссам», надеясь, таким образом, быстрее попасть домой (с. 181). Данное обстоятельство заставляет задуматься об особенностях ментальности военнопленных великороссов и их «личном интересе», когда еще вчера они преследовали патриотовукраинцев, а уже сегодня пытались вырядиться в украинскую «тогу» для того, чтобы поскорее вернуться домой.

C плохо скрываемым «чувством глубокого удовлетворения» О. Нагорная пишет о широком 
распространении контрпропаганды (с. 181), которая велась «прорусски настроенными военнопленными». Если использовать более точные обозначения этой категории военнопленных, то в данном случае речь идет о шовинистах и черносотенцах, - которых было «пруд пруди» даже в национальных лагерях, несмотря на все усилия украинских организаций, имевших целью их изъятие отсюда - с последующим переводом в лагеря общего содержания. Однако, будучи переведенными в смешанные лагеря, черносотенцы находили себе работу и на новом месте - т. к. тут создавались отдельные «национальные» бараки, в которые отделяли украинцев, поляков, грузин, мусульман (после их добровольного на то согласия). В ожидании своей отправки в национальные лагеря «жители» этих бараков иногда были вынуждены пройти все «круги ада», подвергаясь моральной травле и даже прямым физическим нападениям русских черносотенцев.

Еще одним раздражающим для последних обстоятельством было то, что для этой категории военнопленных начинала приходить пропагандистская литература. И вот русские офицеры-чёрносотенцы, по словам О. Нагорной, «проявляли активный интерес» к таким изданиям, считая, что их изучение «позволит позже бороться с предателями». В этих словах - квинтэссенция действительного отношения россиян к политическим устремлениям украинцев и всех остальных народов, имевших «счастье» оказаться в тенетах Российской империи. Предатели России - это все те, кто не исповедует российскую национальную идею и не разделяет ценности «русского мира»- так, по крайней мере, следует понимать логику «мышления» великороссов в изложении О. Нагорной.

А по отношению к «предателям», как известно, все средства хороши - это и списывание номеров украинских активистов (с тем, чтобы при случае передать их царской контрразведке), уничтожение украинских книг и газет, «избиение сепаратистов» (так в тексте О. Нагорной, с. 181), всевозможные враждебные выпады против делегатов СОУ. «В пропагандистских лагерях, - повествует далее 
О. Нагорная, - с помощью слухов патриотически настроенные пленные пытались противодействовать сепаратистской пропаганде среди национальных меньшинств, утверждая, что согласившихся на сотрудничество солдат и офицеров немецкое командование отсылает на фронт». Цитированная фраза О. Нагорной очень хороша для понимания действительного отношения великороссов к украинской освободительной идее, итак - если ты российский патриот, то нет такого злодеяния, на которое ты не пошел для её искоренения!

Безусловно, что этим весь арсенал средств запугивания украинцев не исчерпывался. Российские украиноненавистники активно использовали и такие формы психологического давления как кидание (исподтишка) камней в окна бараков, где проводились занятия в украинских школах грамоты, подкидывание писем с угрозами в украинские бараки; еще одним «ноу-хау» отдельных великороссов в борьбе с украинцами было посещение ими украинских буфетов («чайных»), но не с целью поесть, а только чтобы сломать ложку или вилку, разбить тарелку или чашку, а когда уж совсем «повезёт» и хватит для этого сил - оторвать ножку у стула или стола (Срібняк, 2016).

О. Нагорную обеспокоило то обстоятельство, что «в агитационных (тут: украинских - И.С.) лагерях театральные представления превратились в одно из средств пропаганды сепаратизма и национальной идентификации» (с. 215-216). И в качестве примера она приводит лагерь Вецляр, где «наиболее популярными авторами являлись Т. Шевченко и М. Лысенко». Следуя логике О. Нагорной - было бы во стократ лучше и полезнее, если бы в Вецляре ставились бы только пьесы Чехова или Островского, и таким образом процесс «промывания мозгов» военнопленным украинцам продолжался бы и с театральной сцены.

«Опасность» украинского театра, который вообще-то особенно эффективно помогал узникам переносить тяготы и лишения лагерного быта, приносил хоть на короткое время душевную успокоенность после тяжелой работы, и даже был способен на короткий миг возвратить военнопленных домой (мысленно) - все это, по мысли О. Нагорной - ничто. Главное, 
чтобы театр был русский, а когда он приобретает национальные черты постановкой пьес «только на родном языке» - он превращается в глазах О. Нагорной в одну из форм «пропаганды сепаратизма».

Собственно русские черносотенцы, все еще не вывезенные из Вецляра в смешанные лагеря, тоже понимали силу и влияние украинского театра, поэтому 12 февраля 1916 г. они предприняли попытку сорвать одно из их театральных представлений и таким образом запугать украинских активистов. Во время демонстрации водевиля «Горе не каждому горе, а кому и талант» внезапно в зале случилось какое-то замешательство, а через миг тишину перервали возгласы «Долой Украину!», «Боже царя храни!», «Бей украинцев». Присутствующих в зале охватила паника, которая усугубилась сильной давкой и дракой на последних рядах. Появление немецких солдат и их предупреждения об открытии огня на поражение привело к панике среди военнопленных, которые перестали себя контролировать.

Вследствие этого основная масса зрителей единым потоком кинулась на выход через сцену, при этом были поломаны декорации, потоптаны музыкальные инструменты, а некоторые артисты были просто вынесены этой людской волной из театрального барака. А в зале все еще были слышны песнопения о «хранении» царя-самодержца та проклятия в адрес Украины. Следует также добавить, что это антиукраинская демонстрация стала последней конвульсией черносотенцев в Вецляре, после чего украинская работа в этом лагере продолжалась без каких-либо эксцессов (Срібняк, 2015).

Стоит задуматься - если все это имело место в украинских лагерях, то что же устраивали украинцам черносотенцы в смешанных местах их содержания? Ведь тут даже и апеллировать было некому, не говоря уже о том, чтобы искать защиты. Но и этого украинофобам было мало - и как дополнительный рычаг давления на военнопленных украинцев использовались обращения к лагерным комитетам и благотворительным организациям с предложениями прекращения помощи «сепаратистам». Другими словами любая подлость была хороша, если она препятствовала 
распространению национальных идей, если она сеяла в душах украинцев страх за свою безопасность и судьбу своих близких в Российской империи.

Изучение документов ГАРФ позволило О. Нагорной утверждать, что провозглашение независимости Украинской Народной Республики породило «во всех лагерях (речь идёт о смешанных лагерях - И.С.) противостояние между русскими и украинскими военнопленными». Более того, как отмечает О. Нагорная, они «очень часто переходили в кровавые побоища», однако при этом она не сообщает, кто же выступал зачинщиком этих столкновений. Собственно ответ на этот вопрос лежит на поверхности - тот богатейший арсенал запугивания украинцев, который использовала «черная сотня», позволяет аргументировано утверждать, что русские шовинисты ни перед чем не останавливались, чтобы «поставить на место» украинских патриотов, не побоявшихся защищать украинскую идею в скопищи украинофобов.

На с. 263 украинский читатель найдет очень интересный пассаж О. Нагорной о том, что после поражения Скоропадского имел место «поворот Украины в сторону Советской России». Опять же - автор выдаёт желаемое за действительное - не было такого поворота (если не считать шатаний Владимира Винниченко), и Директория УНР, в особенности после того, как её возглавил Симон Петлюра, оставалась на последовательно антибольшевистских позициях. Другое дело, что Москва вела в это время необъявленную войну против УНР, что, можно предположить, и позволило О. Нагорной утверждать о несуществующем «повороте» Украины.

Остановила своё внимание автор рецензируемой монографии и на лагерных украинских газетах, которые делает «открытие» О. Нагорная - «не предназначались для распространения среди широкой общественности». В этой связи возникает резонный вопрос, - среди какой «общественности» и куда они должны были доставляться? Неужели в Санкт-Петербург или Москву, где бы они внимательно прочитывались членами царского правительства и агентами охранки - для чего те изучили бы украинский язык? Или редакции лагерных газет подготавливали бы для такой 
оказии переводы публикуемых материалов на русский язык?

В числе действительно выходивших газет в украинских лагерях О. Нагорная упоминает фантастические названия не существовавших изданий (в частности - «Союз України»). Тут же содержатся обвинения О. Нагорной в адрес СОУ за то, что лагерные газеты были наполнены антироссийской и пронемецкой пропагандой - как будто бы могло быть иначе! Ограничения военного времени коснулись всех изданий - как в России, так и в Германии, и в силу этого ожидать выхода «беспристрастных», а тем более пророссийских изданий на немецкой земле (так же как и пронемецких в России), абсолютно не приходилось. Газеты военнопленных украинцев в лагерях цензуровались немцами, и уже это одно обстоятельство означало, что все новости мировой политики и события на фронте могли освещаться только в благоприятном для немецкой власти духе.

Не красит О. Нагорную и абсолютно недостойная серьезного исследователя небрежность в написании названий украинских изданий, причем - скорее всего намеренная: в тексте монографии - «Громадска думка», «Громадская думка»

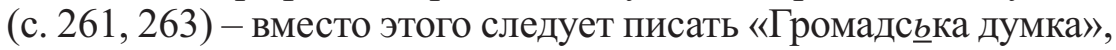
«Ново Заря» - «Нов $\underline{a}$ Зоря», «Вильне слово» - «В $\underline{i}$ льне слово»). Причем - в отличие от русскоязычных лагерных изданий, для которых военнопленные составляли «пассивную читательскую аудиторию», а сами материалы подготавливались в них «только явными сепаратистами», - украинские газеты имели широкий отклик в сердцах военнопленных украинцев, став для них школой национально-патриотического воспитания (Срібняк, 1996; 1997).

И последнее: в своей книге О. Нагорная поместила фотографию с её атрибуцией: «Первый Запасной полк Тараса Шевченко» (с. 431), однако такой формации в украинских лагерях никогда не существовало. Тут без сомнения речь идет о «1-ом Запорожском имени Тараса Шевченко полке» (оригинальное название: «1-й Запорізький імені Тараса Шевченка полк»), который возник на основе лагерной организации «Запорожская Сечь» в Раштате (Срібняк, 2017; 2017). 
Таким образом, внимательное ознакомление только лишь c несколькими сюжетами, касающихся специфики функционирования национальных («пропагандистских») лагерей в Германии во время Первой мировой войны, и в частности - украинских, убеждает в том, что О. Нагорная воспользовалась старыми рецептами российской историографии. В её понимании - национальнопатриотическая работа, которая велась в украинских лагерях членами Союза освобождения Украины, априори не могла иметь позитивного характера, т.к. объективно ослабляла царскую Россию. А какой бы «тюрьмой народов» последняя не была, «своя рубашка ближе к телу», какие бы злодеяния не совершили большевики, и каким бы антидемократическим и нецивилизованным не был бы их режим - делали они это ей на пользу. Это и есть главный посыл и сакральная истина автора рецензируемой монографии в оценке процессов, которые проистекали в национальных («пропагандистских») лагерях военнопленных российской армии.

\section{ДЖЕРЕЛА ТА ЛІТЕРАТУРА}

1. Срібняк I. Табір полонених українців у Зальцведелі (Німеччина) у 1915-1917 рр. // Київська старовина. К., 1997. № 3/4. С.139-151.

2. Срібняк І. Діяльність Союзу визволення України серед полонених офіцерів російської армії в Австро-Угорщині (1914-1918 рр.) // Сурмач. Лондон, 1997. Ч.1-4. С.45-53.

3. Срібняк I. Табір полонених українців у Вецлярі (Німеччина) у 1915-1917 pp. // Вісник Київського державного лінгвістичного університету. Серія «Історія, економіка, філософія». Київ, 1998. Вип.2. С.38-57.

4. Срібняк I. Полонені українці в Австро-Угорщині та Німеччині (1914-1920 рр.). Київ, 1999. 296 с.

5. Срібняк I. Організаційна діяльність Союзу визволення України у таборах полонених царської армії (1914-1916 рр.) // Емінак. 2016. № 2(14) (квітень-червень). Т.1. С.99-103.

6. Срібняк I. Діяльність Союзу визволення України серед полонених старшин-українців царської армії у таборах Німеччини та Австро-Угорщини (1915-1918 рр.). К., 1996. 46 с. 
7. Срібняк I. Полонені офіцери-українці царської армії в таборі Раштат (Німеччина) у 1916 р.: громадський та особистісний вимір таборового повсякдення // Емінак. 2017. № 4(20) (жовтень-грудень). Т.1. С.35-40.

8. Срібняк I. Боротьба світів: формування національної свідомості полонених українців у таборах Німеччини та Австро-Угорщини (1914-1917 рр.) // Історія та історіографія в Європі / За ред. С.Стельмаха і Г.Хаусманна. Київ, 2016. Вип.5: Україна на шляху гідності і свободи. С. 58-68.

9. Срібняк I. Видавнича діяльність полонених українців у Німеччині в 1914-1918 рр. (за матеріалами табірної преси та «Вістника СВУ») // Матер. третього міжнар. конгресу україністів (Харків, 26-29 серпня 1996 р.). Історія. Харків, 1996. C.250-256.

10. Срібняк I. Видавнича та просвітня діяльність полоненихукраїнців у таборі Зальцведель (Німеччина) в 1916-1917 pp. // Центральна Рада і український державотворчий процес (До 80річчя створення Центральної Ради): матер. наук. конф. 20 бер. 1997 р. в 2-х ч. Київ, 1997. Ч.2. С.291-297.

11. Срібняк І. Новітня «Запорізька Січ» на чужині (творення парамілітарних структур в українському таборі Раштат, 1916 р.) // Емінак. 2017. № 1(17) (січень-березень). Т.1. C.80-85.

12. Срібняк I. На службі II-му Райху і Україні: організаційноосвітня діяльність вояків-українців 1-го Запорізького імені Т.Шевченка полку на Підляшші (1917 - початок 1918 рр.) // Гуржіївські історичні читання: Зб. наук. праць. Черкаси, 2017. Вип.12. С.138-144.

13. Срібняк M. I. Створення та діяльність Музичнодраматичного товариства імені М.Лисенка в таборі Вецляр (Німеччина) у 1915-1916 рр. // Дриновський збірник. Том VIII. Харків-Софія, 2015. С.315-321.

\section{АНОТАЦІЯ}

У рецензії в полемічній формі висловлені судження про зміст одного з розділів монографії О. Нагорної "Другий військовий досвід. Російські полонені Першої світової війни в 
Німеччині (1914-1922 рр.)», щуо була опублікована у 2010 р. в московському видавництві «Хронограф». Книга підготовлена в рамках дослідницького проекту Університету в Тюбингені (Німеччина) "Воєнний досвід, війна і суспільство в новий час» i вийшла друком завдяки фінансовій підтримичі Німецького дослідницького товариства. Авторка монографії синтезувала досить репрезентативне коло джерел, у т.ч. значну кількість архівних документів з німецьких та російських архівосховищ, матеріали таборової преси, публічистику та ін. Книга О. Нагорної суттєво розширила уявлення про таборове повсякдення полонених царської армії, фактично вивівии читача на новиц̆ - якісно вищиий - рівень знань про цүю проблему.

3 особливим інтересом читається розділ з ї̈ книги «Німецька політика освідомлення національних меншин Російської імперії: стереотипи, пропаганда і сприйняття», в якому О. Нагорна торкнулася проблеми національних таборів $i$, зокрема, - украӥнських солдатських (Раштат, Вецляр, Зальизведель) та офіцеерського в Ганновер-Мюндені. I якщио говорити виключно про те, як була представлена О. Нагорною інформація про полонених украӥнців (рівно ж як $i$ про представників інших націй), доводиться констатувати, щзо авторка великою мірою залишилась прихильною старим рецеептам щзодо висвітлення політичних прагнень циих багаточисельних національних груп полонених Російської імператорської армії. У сприйнятті О. Нагорної, національнопатріотична робота, яка провадилась в українських таборах членами Союзу визволення Украӥни, апріорі не могла мати позитивного характеру, так як об'єктивно послаблювала цуарську Росію.

Ключові слова: полонені, табір, украӥниі, Російська імперія, Перша світова війна.

\section{АННОТАЦИЯ}

В рецензии в полемичной форме высказаны суждения о содержании одного из разделов монографии О. Нагорной "Другой военный опьт. Российские военнопленные первой мировой войнь в Германии (1914-1922)», которая была опубликована в 2010 2. в московском издательства «Хронограф». Книга была подготовлена в рамках 
исследовательского проекта Университета в Тюбингене (Германия) «Военный опыт, война и общество в новое время» и вышла в свет благодаря финансовой поддержке Немецкого исследовательского сообщества. Автор монографии синтезировала весьма репрезентативныии круг источников, в $m$. ч. значительное количество архивных документов из немецких и российских архивохранилищ, материалы лагерной прессы, публицистику и др. Книга О. Нагорной существенно расширила представления о лагерной повседневности военнопленных иарской армии, выведя читателя, по сути, на новый - качественно высший - уровень знаний об этой проблеме.

С особенным интересом читается раздел её книги «Немецкая политика просвещения национальных меньшинств Российской империи: стереотипь, пропаганда и восприятие», в котором О. Нагорная коснулась проблемы национальных лагерей, и в частности - украинских солдатских (Раштат, Веиляр, Зальиведель) и офицерского в Ганновер-Мюндене. И если говорить исключительно о том, как была преподнесена О. Нагорной информачия о военнопленных украинцах (равно как и представителей других начий), приходится констатировать, что автор во многом осталась верна старым рецептам в освещении политических устремлений этих достаточно многочисленных начиональных групп военнопленных Российской императорской армии. В восприятии О. Нагорной, начионально-патриотическая работа, которая велась в украинских лагерях членами Союза освобождения Украины, априори не могла иметь позитивного характера, т. к. объективно ослабляла иарскую Россию.

Ключевые слова: военнопленные, лагерь, украинцы, Российская империя, первая мировая война.

Надійшла до редакиіі:: 11.10.2018 p. Прийнята до друку: 01.11.2018 p. 